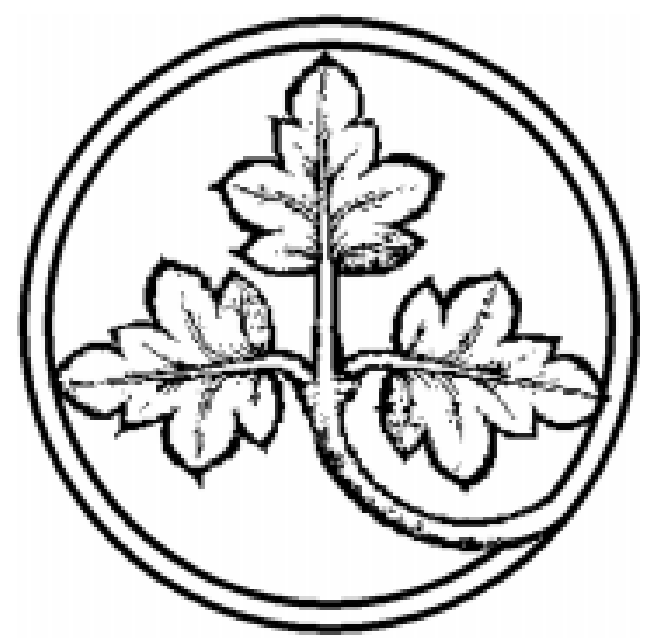

Gemeinschaftsgüter: Recht, Politik und Ökonomie

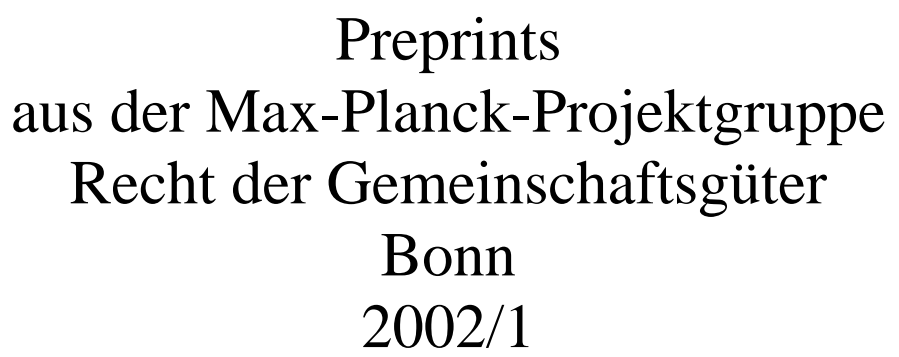

Institutional Dynamics in Environmental Corporatism The Impact of Market and Technological Change on the Dutch Polder Model

von

Henri Tjiong 


\title{
Institutional Dynamics in Environmental Corporatism \\ The Impact of Market and Technological Change on the Dutch Polder Model
}

\begin{abstract}
This paper describes how market and technological change can be conceived to affect corporatist politics in the area of waste management. The paper adopts a political economy approach to institutional change which seeks to trace the impact of market and techological change on established political and regulatory institutions. The paper demonstrates that the main impact of marketization of waste services and the introduction of ISO 14001 environmental management systems was to expand the range of choices for companies and regulators to engage in regulatory interaction concerning environmental waste management practices. The main purpose of the paper is to demonstrate exactly how the emergence of regulatory choices for both companies and regulators is likely to open up new avenues for regulation in the environmental field that, once pursued, systematically reduce incentives for corporate and regulatory actors to engage in associational politics.
\end{abstract}

I would like to thank Tanja Börzel, Christoph Engel, Tom Heller and Wolfgang Streeck for helpful comments on earlier versions of this paper.

\section{Author's address:}

Henri Tjiong

Max-Planck-Projectgroup Common Goods: Law, Politics and Economics

Poppelsdorfer Allee 45

D-53115 Bonn

Tel: 00492289141633

Fax: 00492289141655

tjiong@mpp-rdg.mpg.de 


\section{Introduction}

A key and returning question in political science concerns the continued viability and persistence of the democratic corporatist institutions which have defined the particular brand of Western European capitalism and liberal democracy (Schmitter and Lehmbruch 1977, Katzenstein 1985). ${ }^{1}$ The advent of economic globalization and the concomitant internationalization of governance is thought to affect the coordinative capacities of corporatist actors and the state negatively for a number of reasons already discussed in the literature. Wolfgang Streeck and Philippe Schmitter have theoretically, whilst Wyn Grant and David Coen have empirically investigated the difficulties which corporatist actors (and their complicit states) have encountered in replicating the traditional Western European mode of organizing interests at the European level. ${ }^{2}$ These difficulties relate to the problem of organizing Europe-wide peak associations with similar coordinative capacities as their domestic counterparts, and especially the problem the particular convergence of issue-specific governance and the presence of multiple state authorities-i.e. multi-level governance-imply for the lobbying and co-optation strategies of business interest associations (causing rapid change in associations' internal and external organizational strategies, i.e. political alliances, which make the international associational landscape particularly fluid). However, these difficulties are not absolute. The European Commission, especially, is trying to remove the barriers to an integrated policy approach by actively supporting relevant national associations to arrive at Europe-wide associational representation (primarily by conditioning access to the policymaking process to Europe-wide actors) as well as by the attempt to achieve a one-stop-shop for government services for certain economic sectors where such is possible. ${ }^{3}$ It remains to be seen however whether these practical efforts are sufficient to overcome the more fundamental problems which corporatist arrangements are experiencing under present conditions of economic globalization.

This article takes a fundamentally different approach to the problems which the particular intersection of globalization with democratic corporatism produces for both state and associational actors. Rather than highlighting the short-term and contingent circumstances which prevent the achievement of positive coordination at the international level, it aims to shed light on the longterm and structural difficulties which economic change and market integration signify for the domestic viability of corporatist policies. In particular, this article adopts a political economy approach to the evolution of regulatory policies which aims to describe how market and techno-

1 Philippe Schmitter and Gerhard Lehmbruch (eds.), Trends towards Corporatist Intermediation, Beverly Hills and London, Sage 1977; Peter Katzenstein, Small States in World Markets, Cornell University Press 1985. See in particular, Philippe C. Schmitter, Corporatism is dead! Long live corporatism! in Government and Opposition, 24 (1989) p.54-73.

2 Wolfgang Streeck and Philippe Schmitter, From National Corporatism to Transnational Pluralism: Organized Interests in the Single European Market, in 19 Politics \& Society, no. 2 (1991), p.133-164; Wyn Grant, Pressure Groups and the European Community: an Overview in Mazey, S and Richardson, J., Lobbying in the European Community, Oxford University Press, 1993; Also, David Coen, The European Business Interest and the Nation State: Large-firm Lobbying in the European Union and Member States, Journal of Public Policy (1998) vol. 18 no.1, p. 75-100.

3 See generally, the European Commission's White Paper on Governance, available online at http://europa.eu.int/comm/governance/index_en.htm 
logical forces underpinning globalization at the same time threaten to undermine the functioning of existing-even successful-domestic corporatist policy arrangements. As a result, quite apart from having to counter the threat of external erosion due to positive coordination failures at the international level, this article seeks to demonstrate that corporatism in addition is challengedeven at the domestic level-by the new coordinative potential of alternative regulatory technologies whose adoption threaten to undermine the incentives that have traditionally sustained associational politics.

The structure of the article is as follows. Section 2 introduces a case study on waste management in the Netherlands which focuses on the packaging covenant, chosen here as representative of the class of voluntary agreements - which are in Dutch called covenants - that make up environmental corporatism. This section focuses on the particular associational logics that undergird the establishment of the issue-specific packaging waste association (SVM-Pact) and which explain the positive conditions of the current corporatist policy setting. It continues with a detailed account of the functioning of the packaging covenant and a summary discussion of the difficulties experienced by the Dutch government in the current implementation of the covenant.

Section three tells a story of the dynamically evolving waste market context that has emerged as a result of creeping environmental regulation, and in particular the imposition by the Dutch government of a landfill ban and landfill taxes. It demonstrates that specific changes in the waste market have been compelling enough to induce structural change at the level of political authority and regulatory policy-making. The changes are mainly related to market expansion and internal consolidation strategies which saw formerly small waste management actors mature to professional players whose activities are increasingly characterized by economies of scale due to environmental regulation, and which now span the size of a national market.

Section four discusses the impact technological change can be conceived to have on corporatist arrangements. It examines the increasing company adoption of ISO 14001 environmental management standards and the subsequent response of regulators to this development. The main regulatory response was to transform the existing command-and-control licensing regime into a flexible instrument that can adjust particular licensing requirements to the environmental management practices in place at a particular corporate site. In turn, this flexibilization of licensing presents regulators with new problems relating to the coordination of policy-making competences, monitoring, and enforcement. The solutions sought for these problems are pointing to new possibilities for regulatory control which the state may adopt, if it desires-as this article assumes - to preserve the exercise of independent political authority.

Finally, section five develops the specific ramifications of the constantly evolving market and technological developments for associational politics and corporatist governance. It does so by examining the added political choices regulators and corporate actors have in the new political economy of waste management services. In turn, these choices imply sharply different incentives for these actors to pursue associational politics. Several scenarios are sketched which detail the 
specific transition paths that current corporatist institutions may follow as a result of the multiplication of regulatory choices.

\section{The Corporatist Structure of the Packaging Covenant: How does the 'Polder Model' Work?}

The packaging covenant is a direct exponent of the newly implemented target-group policy in the Netherlands to regulate by "problem pressure" rather than by strict legal mandate and to use tactics of persuasion rather than coercive legal enforcement methods. ${ }^{4}$ In the interest of flexible, effective and enforceable regulation, the government-more specifically, the Ministry of Housing, Spatial Planning and the Environment (VROM)—started a novel policy approach in the mid-eighties which targets regulatory affected groups in order to institutionalize communication mechanisms that facilitate the formulation of policies which meet the broad consensus of the target-groups. ${ }^{5}$ The characteristic feature of the agreements resulting from this approach is that, despite the fact that they are voluntary, these agreements contain "carrot-and-stick" mechanisms which are intended to impose constant "problem pressure" on regulated groups to advance the fulfillment of their commitments. For instance, industries would be compelled to agree in advance with the government to develop environmental business plans with specific timelines and outlines of performance targets. Performance targets, however, are to be defined and set by the companies themselves in order to safeguard corporate autonomy. Within this approach, objectively verifiable aggregate measures such as maximum pollution values or a fixed amount of packaging waste reduction (for example, the $910 \mathrm{kton}$ absolute prevention goal of the packaging covenant) were commonly used as targets that maximally induce companies to live up to their commitments. As such, they were often considered more favorable than relative targets that fix a ratio of environmental performance to a moving baseline (most often, economic growth as measured in per capita GDP).

The packaging covenant is usually cited as a successful example of the corporatist arrangements that lie at the heart of the capitalist economies of the small Western European countries, including the Netherlands, where it is commonly referred to as the Dutch polder model. ${ }^{6}$ In this respect,

4 See generally, Pieter Glasbergen, Partnership as a Learning Process-Environmental Covenants in the Netherlands, in Pieter Glasbergen (ed.). Co-operative Environmental Governance. Public-Private Agreements as a Policy Strategy, Kluwer Academic Publishers, Dordrecht, 1998, p.133—ff. For a short history of environmental policy approaches in the Netherlands with a view to the question of policy learning, see Anthony R. Zito, Patterns of Innovation in 'New' Environmental Policy Instruments: The Case of the Netherlands, paper delivered at the 2001 ECPR Joint Sessions of Workshops, Grenoble, France 6-11 April 2001 (on file with author)

5 For a historical description of the development of the target-group policy within VROM, see, P-J. Klok and S.M.M. Kuks, Het Doelgroepenbeleid in: Milieubeleid-een beleidswetenschappelijke inleiding, P. Glasbergen, (ed.) VUGA Uitgeverij, 's Gravenhage 1994, chapter 4, p.79-ff.

6 The polder model is an endearing term that speaks to the capacity of the Dutch to engage in collective action for the accumulation of new land (polders) in a country invariably short of that resource. For a recent account of Dutch social corporatism, see Jelle Visser and Anton Hemerijck, 'A Dutch Miracle': Job Growth, Welfare Reform and Corporatism in the Netherlands, Amsterdam University Press (1997). See also, F. Hendriks and Th.A.J. Toonen (eds.) Polder Politics: The Re-Invention of Consensus Democracy in the Netherlands, Aldershot, Ashgate, 2001. For studies of Western European democratic corporatism in general, see Philippe 
the success of the packaging covenant can be evaluated from a normative and from a positive perspective. From a normative perspective, several comparative studies commissioned by the European Commission have shown that the packaging covenant consistently performs top of the class in terms of the packaging waste reduction and recycling benefits achieved when measured against the costs. ${ }^{7}$ For example, although the Dutch recycling and reduction quotes are wholly comparable to those achieved in Germany, the estimated 11 euro per capita costs for the voluntary Dutch packaging covenant system relates favorably to the 30 euro per capita costs for the private, but mandatory German DSD (Duales System Deutschland) system. ${ }^{8}$ From a positive perspective - which will be the dominant perspective taken in this section - the packaging covenant is rated as a success in terms of its continued viability and persistence. This can be explained in terms of the positive conditions for the functioning of corporatism identified in the European political science literature. In the following, we will attend to the positive preconditions for the functioning of environmental corporatism — in this case, the packaging covenant.

Let me start by identifying the packaging covenant as an instance of environmental corporatism. I want to distinguish this term from social corporatism, i.e. the more or less centralized structure of interest intermediation that exists in many European countries to mediate class conflict over wages and other labor conditions. The distinction between environmental and social corporatism tracks that between trade associations and employer associations advanced by Schmitter and Streeck (1981: p.38), but not to its full length. ${ }^{9}$ The latter distinction hinges on the degree of interaction with trade unions: the organizational properties of employer associations are directly affected by interaction with trade unions, whereas the structure of trade associations is not. The latter condition is true for associative action in environmental corporatism as well: the packaging covenant's operations as a rule do not include interactions with trade unions, and labor conflicts generally do not influence the implementation of the packaging covenant. However, this is not sufficient to qualify the packaging covenant as a 'mere' trade association. Unlike a trade associa-

Schmitter and Gerhard Lehmbruch (eds.), Trends towards Corporatist Intermediation, Beverly Hills, London 1977; Gerhard Lehmbruch and Philippe Schmitter (eds.), Patterns of Corporatist Policy-Making, Beverly Hills, Sage 1979; Peter Katzenstein, Small States in World Markets, Cornell University Press 1985; Wolfgang Streeck, Social Institutions and Economic Performance: Studies of Industrial Relations in Advanced Capitalist Economies, Beverly Hills and London, Sage (1992)

7 See generally, The Cost Efficiency of Packaging Recovery Systems - The Case of France, Germany, the Netherlands and the United Kingdom, a study commissioned by DG Enterprise of the European Commission to Taylor Nelson Sofres Consulting (on file with author). See also Philipp Axt study (on file with author)

8 See the studies cited above. The cost difference is attributed to the following elements that characterize the Dutch system: (1) the Dutch pick the lowest hanging fruits, in that they aim their reduction efforts only to those material waste streams that lend themselves to easy and cost-efficient recycling. This is especially the case with plastics, where prior Dutch pilot experiments have guided the setting of comparatively lenient reduction and recycling goals in the covenant after finding that recycling plastics was not cost-efficient. (2) the low costs are often attributed to the significance of charities in the collection of waste in the Netherlands where a tradition of picking up old paper and glass existed long before the institutionalization of the packaging covenant.

9 Philippe C. Schmitter and Wolfgang Streeck, The Organization of Business Interests: Studying the Associative Action of Business in Advanced Industrial Societies, MPIfG Discussion Paper 99/1, originally published at the Wissenschaftszentrum Berlin under WZB Discussion Paper, IIM / LMP 81-13. On corporatism generally, see Philipp Schmitter and Gerhard Lehmbruch (eds.), Trends towards Corporatist Intermediation, supra n.1; Gerhard Lehmbruch and Philipp Schmitter (eds.), Patterns of Corporatist Policy-Making, supra n.6; Peter Katzenstein, Small States in World Markets, supra n.1 
tion, the packaging covenant is not limited by a strictly sectoral scope. Rather, because of the encompassing nature of packaging waste reduction goals (all industries-not merely the packaging industry-bringing packaging to the market needed to be included ${ }^{10}$ ), the packaging covenant required a multi-sectoral approach resulting in the covenant being an umbrella agreement coordinating packaging reduction efforts within the framework of the existing sectoral trade associations. The packaging covenant thus carries an additional horizontal dimension uncharacteristic for most trade associations, requiring that additional coordination functions be developed. Accordingly, the cooperation of VNO-NCW, the main employer association in the Netherlands, was essential for the negotiations surrounding the packaging covenant to succeed. This is why VNO-NCW, despite its functional distance to the subject, is a signature party to the covenant, and it also explains why SVM-Pact, the administering organization of the covenant, although not formally connected to VNO-NCW, is nonetheless located within the offices of VNO-NCW and co-financed by VNO-NCW member contributions. This is a clear instance of the dynamics of institutional inertia (Genschel, 1997) ${ }^{11}$, where new coordination requirements are met by using the 'installed base' (Heller) of old institutional structures. Yet the emergence of SVM-Pact, as a new player, seems neither a clear case of patching up —an established organization developing an additional structure "on top of its old" to improve the implementation of its original mandate-nor of transposition - an old organization revamping in order to attend to new functional requirements. Rather, the packaging covenant contains elements of both in that a new organization with a new functional mandate (SVM-Pact) is built with the financial support of, but with formal functional independence from, the old organization (VNO-NCW).

Before we can discuss the specific relevance of SVM-Pact's "piggy-backing" on the institutional structures of VNO-NCW, we have to explore in more detail the organizational requirements associated with business interest intermediation. As Streeck and Schmitter explain, the organizational development of business interest associations (BIAs) can be described in terms of the logic of membership and the logic of influence. As interest intermediaries, BIAs must develop a Janushead-like capacity to serve both the members whose interests they wish to protect as well as the state whose authorized coercion they wish to influence. Facing their members, BIAs sell services and "selective goods" (Olson, 1965) ${ }^{12}$ to members and must allow for participation by members in the creation of "consensus" around solidaristic goals (logic of membership, Schmitter and Streeck, p.24-ff). Facing the state, BIAs attempt to develop a control capacity over their members in an effort to "sell" compliance to the state and to try to represent the interests of their members vis-à-vis the state. The latter is done by exerting lobbying pressure for the particular public policies which the state controls (logic of influence, Schmitter and Streeck, p.30-ff). As a rule, these two logics - which Streeck and Schmitter describe as outward-looking because of the external constituents that have to be pleased-compete with each other in the choice of an ap-

10 The convention in the packaging covenant is to term the combined packaging industry and industries bringing packaging to the market as "the packaging chain".

11 Philipp Genschel, 'The Dynamics of Inertia: Institutional Persistence and Change in Telecommunications and Health Care', in: Governance 10, 43-66

12 Mancur Olson, The Logic of Collective Action: Public Goods and the Theory of Groups, Harvard University Press, Cambridge, Mass. 1965 
propriate organizational strategy for the association. According to Streeck and Schmitter, it is only when these external demands have been sufficiently met and stabilized by appropriate institutionalization (membership dues are formalized, channels of membership compliance have been developed, internal decision-making procedures have been institutionalized either by simple majoritarian voting or by weighted voting, and appropriate channels of influence are established with the state) that a business interest association can move on to the next stage and transform itself to a "private interest government". The existence of a private interest government presumes the successful consolidation of a BIA into the service of "private governance": a set of more inward-looking organizational strategies characterized by the ability to formulate goals with relative independence and to follow up with their effective implementation (Streeck and Schmitter term this the logics of goal formation and effective implementation, respectively). ${ }^{13}$

The significance of "piggy-backing" SVM-Pact upon the existing structure of VNO-NCW can now more fully be appreciated in terms of the negotation as well as the implementation of the packaging covenant. Without VNO-NCW's established membership base, it would be difficult for SVM-Pact to develop the credibility to negotiate directly with the Dutch central government to represent the interests of the packaging chain and to seek the voluntary cooperation of industry and secure industry compliance with the covenant. Similarly without VNO-NCW's secure financial resources (through formal membership dues), it would be difficult for an organization to run a limited (four person), yet full-time paid professional staff solely to represent the limited business interest of controlling packaging waste regulation. It is this piggy-backing upon VNONCW's members' institutionalized loyalty and financial resources that allows SVM-Pact to assume-nearly from "scratch" - the function of private interest governance, with its distinctive focus on the "inward-looking" logics of goal formation and effective implementation-as opposed to the "outward-looking" logics of membership and influence. Yet, although its primary organizational strategy does not directly attest to the need to serve the logics of membership and influence, this of course does not mean that SVM-Pact is not informally constrained by VNONCW's associational interests or those of some of its larger individual members. It is even conceivable that these interests pose significant constraints to the organization's operation and independence, and are important enough in practice to threaten SVM-Pact's new and still tenuous function of private governance. ${ }^{14}$

13 Streeck and Schmitter [Organization of Business Interests], see n. 8

14 The issue here is one of inter-organizational coordination of policy which is reminiscent of the intraorganizational coordination issue implied in the conflict of interest between professional staff and elected leadership of assocations often cited in corporatism literature. 


\subsection{Defining a Functionalist Research Perspective on Corporatist Governance}

The main line of investigation to be explored, however, has little to do with a classical incentive or power-based analysis of the collective action problems existing within, and between the powerful old association-VNO-NCW-and the new, less powerful "private governance" association-SVM-Pact. Rather, I would like to analyze more broadly the intrinsic, functional, or "technical" problems of corporatism in obtaining regulatory commitments. In so doing, I will attend to a distinction between environmental and social corporatism insufficiently explored in the corporatist literature, which focuses on the more technical dimensions of corporatist monitoring and enforcement.

The distinction between environmental corporatism and social corporatism is material mainly when looked at from a monitoring and enforcement perspective. In social corporatism, the commitments that employer associations and unions make typically concern wages and working hours, and secondary labor benefits, such as vocational training, pension benefits, early retirement provisions, etcetera. From an enforcement perspective, these commitments-once negotiated-are easily ascertainable and are not subject to scientific uncertainty (hence legal uncertainty in ex post court judgements is reduced). The relatively "hard" character of these commitments therefore allow interest representative associations (both employers and unions) the continued ability to monitor their members and hence to guarantee their capacity to "sell" compliance to the state.

In contrast, the policy commitments associated with environmental corporatism deal with emission values, toxicity levels, recycling quotas, and waste limit values. These pose scientific obstacles to quantification, are subject to conflicting interpretation, characterized by constant technological innovation, and contain goal-specific ambiguities (what constitutes adequate environmental protection); the combined influence of which produces extremely difficult problems for monitoring. Since associations are as little adapted to deal with these problems - of monitoring and continual policy updating - as bureaucracies are, it is foreseeable that environmental corporatism should encounter considerable difficulties in producing the same compliance credibility that has made social corporatism a viable method of policy implementation. This functional perspective on the capacity of environmental corporatism to deliver credible commitments will provide the critical lens that will guide the following discussion.

\subsection{The Administration and Implementation of the Packaging Covenant}

The packaging covenant was signed by the following six parties. On the public sector there was the Ministry of Housing, Spatial Planning and the Environment (VROM), the platform for Dutch provinces (IPO), and the association for Dutch municipalities (VNG). The private sector ("the packaging chain") was represented by the Foundation for Packaging and the Environment (SVM-Pact), the Netherlands main employer association (VNO-NCW), and the association for 
small and medium enterprises in the Netherlands (MKB-Nederland). ${ }^{15}$ The packaging covenant sets up a system for the reduction and recycling of packaging waste, which, in order to coordinate packaging reduction and recycling efforts, uses (1) sectoral trade associations and (2) recycling foundations. The structure of the packaging covenant can be depicted as follows:

\section{Fig. 1: The structure of the Dutch packaging covenant}

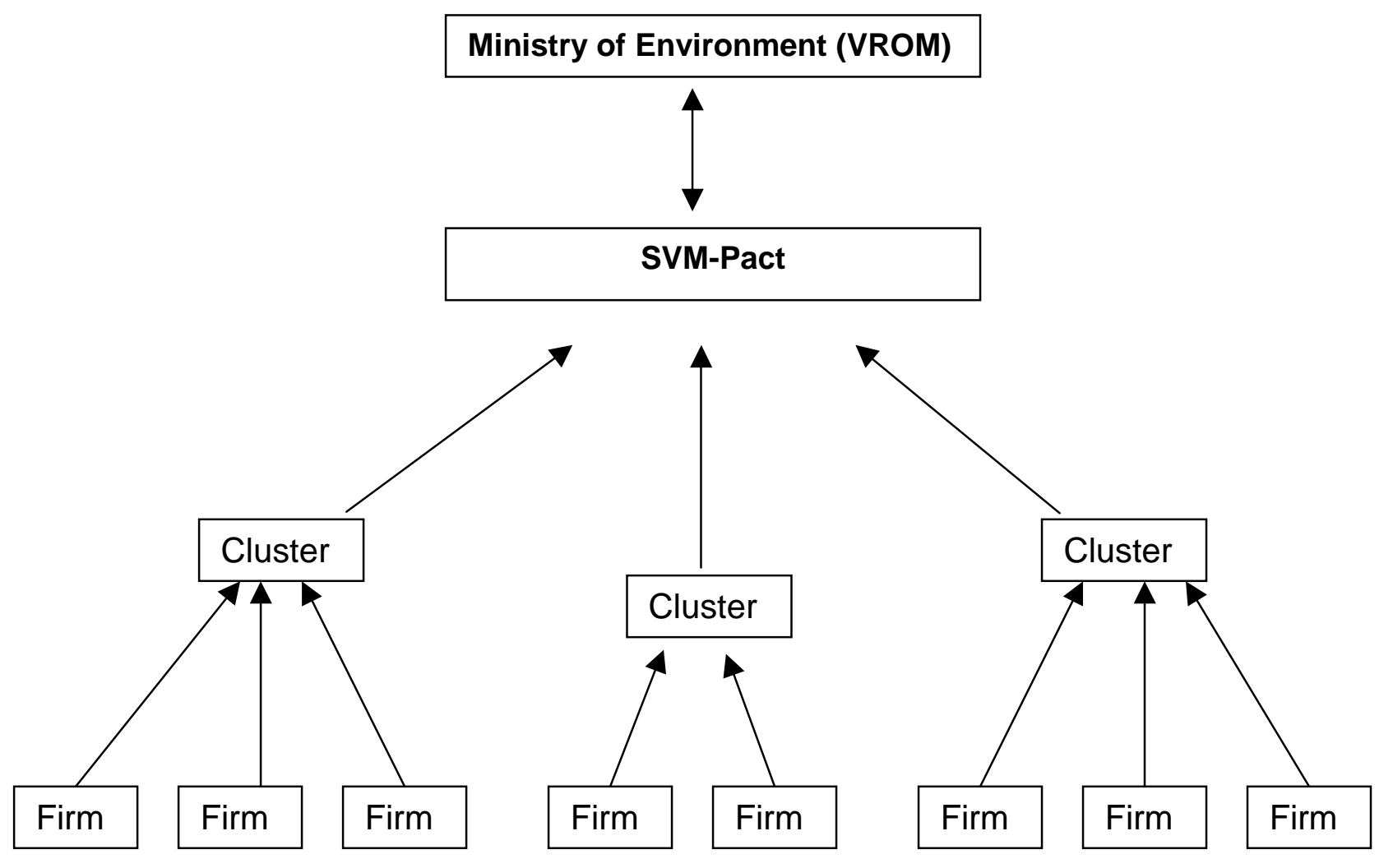

Ad 1) Coordination by the sectoral trade associations for packaging reduction

Industry is organized in clusters that correspond to the traditional SBI classification adopted for statistical purposes by the Central Bureau for Statistics (CBS). These clusters are generally made up of the traditional trade associations of the industry sector, although there are instances in which clusters have been set up anew for specific packaging reasons by small groups of companies (sometimes with as little as two members). SVM-Pact administers the system and is the executive organ of the covenant. It coordinates the activities of the clusters and has set up an account-management system to service companies that have signed up to participate in the packaging covenant.

15 Preamble of the 2nd Packaging Covenant (1997), Convenant Verpakkingen II (on file with author), also available at http://www.svm-pact.nl/convenant/convenantindex.html.

Or http://www.vrom.nl/pagina.html?id=100 
The hallmark of the covenant is that the obligations and administrative burden it imposes on companies are minimal when compared to a mandatory regime of packaging reduction obligations. In order to comply with the obligations of the covenant, companies must:

(1) File annual reports to SVM-Pact on the amount of packaging marketed in the Netherlands by the individual company and by the holding. The total amount is measured in weight and broken down in specific packaging material (i.e. paper, plastic, glass, etc.).

(2) Fill out an annual survey that investigates the relevant context of packaging waste reduction in the company, i.e. the questionnaire asks whether packaging reduction measures have been taken; the degree to which packaging weight could be reduced; whether power over suppliers is sufficient to influence packaging design, etc. ${ }^{16}$

In addition, companies commit themselves to voluntary packaging reduction efforts through a review of product design and packaging production processes. These efforts are coordinated by the clusters (i.e. the representative sector associations), which, for their part, also serve to redistribute industry knowledge on packaging reduction techniques and opportunities. The packaging covenant's provisions encourage company experimentation and sectoral and cross-sectoral cooperation. In the latter case, vertical cooperation throughout the packaging chain is often coordinated by the clusters (viz. in transport packaging, there are several cases in which narrow cooperation between packaging suppliers and manufacturers at the level of engineers and product designers resulted in redesigning transport packaging requirements).

Company figures on the annual packaging marketed is aggregated at the cluster level and anonymized. Clusters in turn remit these figures to SVM-Pact, which checks these figures at the cluster level against previous historical measurements and against the industry average. In cases of conspicuous and a-typical deviations, SVM-Pact will investigate the reasons for such deviation at the cluster level, which in turn may investigate at company level. In some instances, SVM-Pact may investigate directly at the company level. On-site visits are conducted by SVMPact, usually in cooperation with sectoral associations to investigate such cases, to provide information on the packaging covenant, and to collect case-by-case information on industry packaging reduction experiments.

\section{Ad 2) Coordination by material recycling foundations for packaging recycling}

The second category of implementation actors in the Dutch packaging covenant are the material recycling foundations. Material recycling is organized per waste stream. In the Netherlands, there traditionally have been separate kerb-side collection mechanisms for the different waste streams: paper/cardboard, glass, wood, metals, and to a much more limited extent, plastics. These individual waste collection and recycling companies are organized in their respective ma-

16 The obligations in this concrete form are not immediately apparent from reading the covenant which only specifies aggregated performance obligations, i.e. for the packaging chain as a whole. However, they reflect the daily operations of the covenant as detailed in an interview with Mr. Rob van Beek, an official at SVMPact. 
terial association, and so we have the paper/cardboard recycling foundation, the glass recycling foundation, the recycling foundation for wood, for metals and for plastics. These associations collect packaging waste recycling figures from their individual members and produce an annual aggregated figure per waste stream, the so-called annual recovery measure.

At this point, it is appropriate to examine (the main contours of) the monitoring system as detailed in a separate monitoring protocol of the covenant. Figure two explains how the main dimensions of the system hang together.

\section{Fig. 2: The structure of the covenant's monitoring system}

Market measure

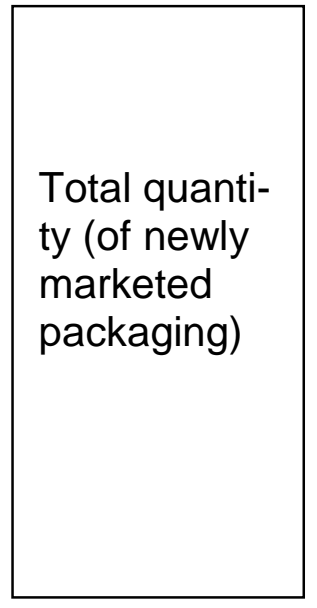

Waste measure

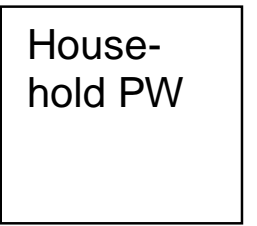

Industry

PW
Recovery measure

Landfilled

and inci-

nerated

PW

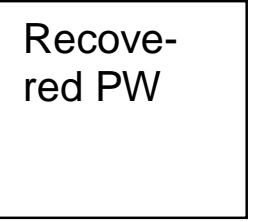

The monitoring system relies on three "hard" measures: (1) the market measure, i.e. the total quantity of packaging marketed in the Netherlands in one year (conducted by SVM-Pact); (2) the waste measure, a measure collected by an annual sample survey among municipalities concerning the amount and composition of household waste (conducted by VROM); and (3) the recovery measure, which is provided annually by the material recycling foundations on the basis of aggregated figures of their members.

The three "hard" measures allow for two important values to be calculated: the total amount of industrial packaging waste and the total amount of landfilled and incinerated packaging waste per annum. It does this on the basis of the following methodology. Based on the short life-cycle of packaging, it is assumed that the total quantity of packaging marketed in one year equals the total quantity of packaging waste derived from households and industry. Similarly, the total quantity of marketed packaging is assumed to equal the quantity of recycled packaging waste plus the amount reserved for final destination. Given this dual assumption-that input will equal output - the monitoring protocol calculates the quantity of industry packaging waste by subtracting household waste from total marketed packaging (i.e. the market measure) as it calculates the amount of packaging waste reserved for final destination (i.e. landfill and incineration) by sub- 
tracting the amount of recovered packaging waste from the market measure. The dotted boxes hence indicate inferred values that are not actually measured, but are calculated on the basis of the other boxes. ${ }^{17}$

\subsection{Evaluating the Results of the Packaging Covenant: Going Beyond Common Implementation Analysis of Policy Failure}

As was mentioned before, the Dutch approach to managing packaging waste is generally evaluated as successful. The latest published waste reduction results for 1999 fall well within the targets set by the packaging directive, and are not far from the final targets set by the packaging covenant for 2001. Let us briefly examine what these targets are, and examine how the polder model performs in the area of packaging waste management.

Packaging directive 94/62 EEC leaves member states free to establish their own systems of packaging waste management, but establishes a range of quantified targets within which member state commitments have to fall. The European targets are established in Art. 6.1 of Directive 94/62 EEC. They specify the packaging waste reovery and recycling quotes that member states are obliged to achieve by 30 June 2001. Material recovery, which combines material recycling and the use of recovered waste for secondary purposes (examples include: waste as component material in cement, burning fuel for coal-firing electricity plants, fuel in incineration facilities with energy recovery) is set at 50\%-65\% weight percentage of overall packaging marketed. Within this general recovery goal, a component of 25\%-45\% material recycling of packaging waste (recycling of waste for re-use as raw material) must be reached in the member states.

The Dutch packaging covenant establishes higher recovery and recycling targets than the European directive. The covenant does not have a recovery target, and sets only recycling targets. However, although the covenant does not regulate recovery explicitly, it is estimated that in practice the covenant has led to nearly $100 \%$ material recovery of packaging waste. ${ }^{18}$ The covenant's overall recycling target is set at $65 \%$, with minima per material waste stream which are each higher than the $15 \%$ prescribed by the directive. Figure 3 shows the published results of the packaging covenant for the years 1998 and 1999.

17 See Annual Report 1998 presented to the Packaging Committee, available online at http://www.svm-pact.nl/convenant/download-convenant.html

18 See Markus Haverland, National Autonomy, European Integration and the Politics of Packaging Waste, (1998) p.242 
Fig. 3: Material recycling targets and results ${ }^{19}$

\begin{tabular}{|c|c|c|c|}
\multicolumn{2}{c}{$1998(\%)$} & $1999(\%)$ & 2001 targets \\
\hline paper/cardboard & $70(47)$ & 70 & 85 \\
\hline Glass & $85(84)$ & 91 & 90 \\
\hline Metals & $79(78)$ & 77 & 80 \\
\hline Plastics & $14(10)$ & 17 & 35 \\
\hline Total & $62(49)$ & 63 & 65 \\
\hline
\end{tabular}

Note: The monitoring methods in 1998 are too deviant from those in 1997 to allow comparison. The 1998 results were adjusted in 1999 for monitoring irregularities. The originally published figures are bracketed. The adjustments show the covenant results in a more favorable light.

However, the impressive results of the Dutch packaging covenant must be qualified by two general, and two specific qualifications. I will deal with them in decreasing order of generality. Firstly, the figures reflect an under-inclusive figure regarding the total amount of packaging brought to the Dutch market. Although the SVM-Pact has committed itself in the covenant to achieving a $90 \%$ packaging coverage ratio-i.e. to bringing $90 \%$ of companies' marketing packaging in the Netherlands within the scope of the covenant-it achieved a $66 \%$ coverage ratio in 1998. More worryingly for SVM-Pact's credibility and that of the packaging covenant as a whole, in 1999 this ratio dropped to $59 \%$ of the total firm population, despite vigorous efforts by SVM-Pact to increase firm membership in the covenant (by public campaigns and company admonitions). Secondly, the aggregated packaging reduction figures at the level of political monitoring — specified in the protocol—makes the sale of compliance difficult for SVM-Pact. As was said before, clusters collect data at the company level, but aggregate and anonymize this data to avoid competitive repercussions from the information otherwise released. The aggregated form of the data, however, makes it impossible to zero in on the individual company experiencing difficulties in packaging waste reduction, which in turn impedes SVM-Pact from evolving into an active help-desk with the ability to propose concrete management solutions. In addition, the intransparency of corporate monitoring and its aggregated nature also make the covenant vulnerable to citizen and NGO protest, which has materialized, for instance, over the recalculation of 1998 figures, which report an abrupt increase in recycled packaging waste (esp. paper/cardboard), allowing the covenant to be represented as much closer to target than before. Not surprisingly, the NGOs have disparaged the accuracy of those monitoring methodologies, which only allow aggregated monitoring and hence permit individual subterfuge-making corporate commitments correspondingly hard to verify.

19 See Annual Report 1999 presented to the Packaging Committee, available online at http://www.svm-pact.nl/convenant/download-convenant.html 
The third implementation deficit relates to the fact that not all recycled packaging waste streams are processed by the designated material recovery foundations. This is because not all recycling companies have signed up as members of the relevant packaging recycling foundation and, hence, an unknown amount of recycled material is not monitored and not reported. The fourth and final implementation deficit relates to the disappointing figures for paper/cardboard and for plastics as measured against the covenant's own 2001 targets. These figures reflect growing problems with separate collection efforts at the municipal level. Paper/cardboard collection mechanisms were traditionally run by charities with collection prices at break-even level or, which at the most, were operating with marginal profits. Paper collection prices are put under pressure by falling market prices for recycled paper, which threaten to turn paper collection into a negative profit enterprise. Not surprisingly, collection charities are experiencing rising difficulties in finding volunteers to collect old paper, and in some instances they have ceased operating altogether. With regard to recycling plastics, the disappointing results can be explained by the practical difficulties of separating plastic packaging waste from general household waste. Although most Dutch households separate their waste in special bins, the required facilities for further processing separately collected waste are often lacking at the municipal level. ${ }^{20}$ The amount of recycled plastics can only be increased if separate collection processing facilities are more vigorously implemented by municipalities. In order to address this implementation deficit, the Ministry of Environment (VROM) is involved in an extensive information and education campaign to improve the commitment of municipalities to separate waste collection programs. ${ }^{21}$

Having given a current picture of the operation of the covenant and its related problems, I want to briefly discuss some of the underlying reasons behind the typical implementation deficits relating to the covenant approach.

At first hand, the four implementation deficits of the packaging covenant seem to point to the two old problems that beset any approach that relies on voluntary compliance, namely how does one guarantee as encompassing a participation rate among relevent actors as possible? And secondly, how does one subsequently monitor whether individual parties have complied with covenant obligations? $?^{22}$

This line of analysis, however, (too) easily suggests that the problem with the covenant approach is the unwillingness of companies to sign up to voluntary packaging reduction agreements, and to provide company-level data which would have made monitoring easier, but which would also

20 The Dutch situation is unlike that in Germany where the DSD "grüne punkt" system—a separate private system of waste collection and management-operates independently of municipal waste collection and guarantees a separate collection and processing of packaging waste that is marketed with a "green dot".

21 Separate programs for separate waste collection were set up for household waste and corporate waste, GIHA and GIBA, respectively (GIHA stands for Gescheiden Inzameling Huishoudelijk Afval, GIBA for Gescheiden Inzameling Bedrijfsafval). They are targeted at municipalities and companies to build facilities for separate collection and processing of waste.

22 This line of analysis of policy failure, perhaps somewhat unfavorably, I have earlier associated with common implementation analysis. However, implementation analysis did also emphasize strengthening the focus on learning as an integral element in effective implementation, see generally Jeffrey L. Pressman and Aaron Wildavsky, Implementation, University of California Press 1973 (see especially preface to the third edition, 1984) 
have meant substantial adaptation pressure for companies. The depiction of a general industry commitment problem, however (if possibly true), too quickly recommends tightening political hierarchical oversight and the institutionalization of mechanisms to improve that oversight-e.g. by imposing mandatory producer-responsibility obligations. However, it may be questioned whether this analysis - in the end-is very helpful and/or whether the real problem lies not with the lack of industry commitment, but with the untapped potential for what has in another context been called "no regrets" solutions, i.e. solutions that lie at the low economic cost range, or introduce economic cost savings over time, while simultaneously providing net environmental benefits-which, importantly, can be assessed only after environmental action has been taken, and which thus require a certain amount of economic risk-taking. ${ }^{23}$ From this perspective, the covenant's troubles relate less to its voluntary nature, than to the inadequate institutionalization of incentives for technological and commercial risk-taking that can trigger environmental innovation. In general, these problems relate to the current lack of knowledge concerning waste reduction possibilities at the company level, their commercial applicability for profitable marketization, the spread of this practical knowledge to as wide of a relevant actor base as possible, and the potential competitive distortions arising from industry and regulatory cooperation.

Solutions to these separate institutional problems are not immediately suggested here. What I want to do in the following sections is to focus on two contiguous developments in the waste management sector which imply a change in the waste regulatory context to which the Dutch government, to some extent, is already adjusting its general waste and licensing policies (but not its specific packaging waste regime) in a general anticipatory fashion. The general impact of these changes, I argue, is to expand the space for so-called "no regrets" solutions. They are the following market and technology forces:

1) The professionalization and consolidation occurring in the market for waste management services.

2) The increasing use of environmental management systems, such as ISO 14000 and EMAS, that allow for internal governance and external reporting to the community for public relations and regulatory purposes.

Section 3 will discuss the fluctuating market developments in the sector which impinge on Dutch waste regulations, while section 4 will examine the regulatory implications of technological and organizational change related to the growing adoption of environmental management systems by medium and large-sized companies.

23 Hence the term, "no regrets". The concept of "no regrets" speaks to an audience of economists, who start from the assumption that business firms are categorically better in discerning the market's demand characteristics than government. Therefore, if the market had demanded environmental innovation, it would have delivered it. There is no role for government in the structuring of the supply of environmental innovation. However, the concept of "no regrets" qualifies this categorical statement in that it introduces the more realistic assumption that economic risk-taking is required for companies to engage in environmental innovation. And that, therefore, the government may well play a crucial role in mitigating that economic risk for companies. See David Victor, The Collapse of the Kyoto Protocol and the Struggle to Slow Global Warming, Princeton University Press (2001) p.98 


\section{Market Expansion and Horizontal Integration in the Waste Management Sector}

The last fifteen years have seen a number of significant changes taking place in the Dutch waste market, the ripple effects of which are still seen today. They started in the second half of the nineteen eighties when American waste management companies-mainly Waste Management Inc. and BFI-started to operate in the Dutch market. The strategy of these companies was to buy up numerous little firms, which collected mainly industrial or commercial waste. The reason for this strategy was that industrial waste has traditionally proven to be the most easily profitable segment of the market. Due to the relatively low number of industrial sites and the concentration of waste to be collected, operating costs can be kept low in comparison with household waste; and economies of scale can be achieved relativily easily. Accordingly, the market strategy of Waste Management and BFI was to obtain a dominant position in the industrial waste collection market, which would allow these companies to command prices vis-à-vis corporate waste suppliers.

Around the same time, however, the Dutch government was being confronted with a series of scandals that involved heavily dioxine contaminated landfill sites, the most famous one being the "Lekkerkerk affaire". From that time on, the government started to get serious about imposing environmental obligations on the waste sector. Landfill regulations that commanded mandatory clean-up and preventive measures for groundwater pollution prevention were adopted which made the operation of landfill sites increasingly expensive. Many small municipal landfill sites were closed and a process of municipal and later provincial consolidation was started.

In addition, the prevailing political conception of proper waste treatment was summed up by the so-called "Ladder of Lansink", which referred to a Dutch member of parliament who proposed to order political preferences by arranging waste treatment options from those having the least impact on the environment to those having progressively more impact. This preference order was subsequently enshrined in the "Wet Milieubeheer" (law on environmental management). According to the "ladder of Lansink", prevention of waste is most desirable, followed by re-use, material recovery and recycling, energy recovery, incineration and finally landfill.

In this politics-guided view, landfill was to be curbed to a minimum. The Dutch environmental ministry imposed a ban on landfill ${ }^{24}$ and raised waste disposal levies so as to bring tariffs of landfill to the same level as those of incineration. Incineration facilities now had to comply with strict emissions requirements, which meant that expensive desulphurization installations (scrubbers) needed to be installed. In total, eleven incineration facilities were built, whose cost-

24 Besluit Stortverbod Afvalstoffen (BSA). The ban of course is not absolute. Landfill sites are still operating in the Netherlands, but permits ("ontheffingen") must be obtained from the ministry to dispose of waste in landfills. This permit regime is characterized by the usual enforcement problems surrounding command-andcontrol regulation. In particular, the category of non-usable construction waste (niet-herbruikbaar bouw- en sloopafval) is apt for abuse. Since this category of waste can be disposed of under cheaper rates, companies have incentives to mix all sorts of waste with non-usable construction waste in order to exploit cheap disposal options. See VROM persinformatie, Inspectie Milieuhygiene (VROM): Overtredingen stortverbod bouw- en sloopafval (27-12-99) available at http://www.minvrom.nl/minvrom/pagina.html?id=807 
effective finance and operation required that waste streams in the Netherlands be rationalized and reorganized. The heavy initial investments in incineration facilities were made by obtaining municipal and provincial bank loans at lower government interest rates. They were combined with twenty to thirty year operating contracts with financial guarantees made by municipalities to tie municipal waste to its respective facility (municipalities in their role of owner-operators). This financial structure required capacity planning at the ministerial level and a provincial coordination of waste streams to avoid leakage, which would otherwise have threatened the financial viability of the municipalities and provinces. Accordingly, a moratorium on additional incineration capacity was set, and the administrative map of the Netherlands was rearranged in five autonomous waste regions, which planned and controlled waste streams so as to prevent leakage. Leakage was the main problem, since the artificial structure of provincial borders allowed considerable differences in the tipping and incineration fee structure to exist-and persist-which would have triggered arbitrage in a normal market.

On the market side and for the private sector, however, these public sector strategies regulating landfill and incineration started to have major reverberations. With the increasing elimination of cheap disposal options, for example, the strategy of American waste companies to gain market dominance in the collection market so as to be able to command prices, collapsed. They gradually started to divest from the Dutch market. Waste management has now discontinued its operations altogether and has been taken over by Shanks, a British limited company, while BFI has merged with SITA, a Belgian subsidiary of a French holding company.

On the other hand, the very same set of regulations (i.e. regulations on clean-up and after-care of landfill sites, the landfill ban and tax, and strict emissions requirements making for high incineration prices) did not merely lead to divestment out of the sector, but also produced new opportunities and strategies for new market entrants. The new entrants included foreign waste management companies, such as Suez de Lyonnais des Eaux, SITA and, more recently, Shanks, but also transformed domestic waste facility operators, such as AVR (Afvalverwijdering Rotterdam) and van Gansewinkel, who copied the integration concept of the foreigners. In addition, there has also been a major entrant from the energy sector, Essent, which has managed the transition to the integration concept quite successfully. ${ }^{25}$ Rather than focusing on one particular segment of the market-viz. the collection of commercial waste-as the Americans had done, the new regulatory structure which raised final disposal costs to a level higher than in an unregulated market, ${ }^{26}$ turned integration of waste management services into a profitable commercial enterprise. Accordingly, the organization of waste management services changed from segmentation to integration as activities in the whole waste management chain-i.e. collection, recovery, recycling

25 The story of Essent is, as some market analysts say, typical for the future of the utilities sector. Having emerged from the fusion of two energy companies, PMG and EDON, Essent has diversified its operations into the cable and telecom sector (Essent Cablecom) and particularly the waste management sector (Essent Environment). The structure of Essent, however, still reflects its public sector origins. It is a "structuur NV", with main shareholders continuing to be the provinces (76\%) and municipalities (22\%). Privatization of Essent is planned, but recent Dutch legislative changes have made this option less attractive.

26 There is of course considerable debate as to whether the WBM tax internalizes environmental costs and so reflects the true costs of waste disposal. 
of specialized materials, landfill, incineration with energy recovery, and biomass energy production-became complementary services that could be assembled under one corporate concept. ${ }^{27}$ This process of horizontal, or more aptly, service integration has led to a consolidation of the waste management sector, the effect of which is that there are now (only) five major conglomerates which collectively control $44 \%$ of the total Dutch waste market. The rest of the market remains in the hands of local municipalities and individual companies whose small scale activities continue to center predominantly around the collection of household waste. Figure 4 presents the five largest waste management companies according to turnover, which have become known in the policy community as the five so-called "integrators".

Fig. 4: Turnover of the five largest players in the Netherlands (1998)

\begin{tabular}{|l|c|}
\hline Organization & Turnover in NLG millions \\
\hline 1. $\quad$ Essent (PMG, Edon) & 1,065 \\
\hline 2a. Sita & 500 \\
2b. Watco & $360^{\star}$ \\
\hline 3. AVR & $560^{\star *}$ \\
\hline 4. Van Gansewinkel & 450 \\
\hline 5. Shanks Ltd. (Waste Management) & 425 \\
\hline Total & $\mathbf{3 , 3 6 0}$ \\
\hline
\end{tabular}

* Watco's turnover in 1999 was app. NLG 500 million, with both subsidiaries making about the same contribution

** The AVR's turnover grew in 1999 to app. NLG 800 million

Source: Annual Reports, Rabo, as quoted in AOO 2000-0, The Waste Market: Structure and Developments

The distinctive feature of these integrators is that they, in contrast to traditional refuse collection companies, have the capacity to offer client companies the entire range of waste treatment op-

27 The integrators bundle traditionally distinct waste management services, which include: Industrial and commercial waste collection, recycling and composting facilities, waste treatment, solvent recovery, fuel blending, incineration, landfill soil washing, contaminated land remediation, asbestos disposal, waste to energy projects, aggregate recycling, plant and laboratory decommissioning, mobile technical services, on-site project management, waste auditing, consultancy, radioactive waste disposal and total waste management projects. In this respect, the integration concept of the waste utilities can and must be distinguished from the concept of horizontal integration where multi-utilities span the boundaries of multiple sectors. A corporate example of horizontal integration is the multi-utility Essent, which combines energy, cable telecoms and waste services. For a discussion of the development of multi-utilities, see generally, Dirk Sommer, MultiUtilities: Blurring Industry Boundaries, available at http://www.worldbank.org/html/fpd/notes/227/ 227 summary.html. Horizontal integration seems also to be promoted by recent public policy initiatives in the Netherlands which seek to achieve emissions reduction goals through waste management policy. In this regard, the Kyoto Protocol promises to make the waste management sector more interesting for energy companies. The Dutch environmental minister, Jan Pronk, negotiated with the energy utilities the so-called Coal Covenant (Kolenconvenant) in which it was agreed to use a certain percentage of (upgraded) refuse as biomass fuel for energy plants which counts as a contribution to $\mathrm{CO} 2$ emissions reductions. This trend is reflected in the structure of the Dutch waste industry where the largest "integrator" Essent is the biggest multiutility player in the Netherlands whose core activities span the sectors of electricity generation, cable and telecoms, and waste management. 
tions. They present themselves to client corporations as credible service partners with the professional expertise to responsibly and comprehensively analyze and take care of their entire waste stream. They can also ensure that the company meets all relevant national and local government regulations. Thus, in principle, all sorts of companies can outsource their entire waste management to these "integrators", who make full use of the market created for them by the environmental regulations issued by government.

In turn, the integrators also present themselves towards the government as responsible partners who can and should play an important role in the implementation of government waste policies by ensuring sound waste management practices on the part of industry. Not failing to notice the earlier mentioned municipal problems regarding the separate collection of wastes, the integrators have turned to the government to showcase the full gamut of processing possibilities for industrial wastes that they make available, varying from material recovery, recycling, and transformation to biomass for biofuel applications. ${ }^{28}$ In that respect, it is perhaps notable that most of the current integrators hail from countries with a strong public sector. Sita is from Belgium, and Watco is a subsidiary of Suez Lyonnais des Eaux, a French company with extensive experience in working with the French public administration. Essent, AVR and van Gansewinkel are domestic players with a long-standing tradition of public sector dealings (local governments are still the majority shareholders). They have replaced the American companies, which are arguably less experienced in dealing with an extensive and intrusive public administration, and which come from a regulatory tradition in which government restricts itself to setting general conditionsoften described as bright-line rules-for market operation.

The most noticeable consequence of integration and market expansion is the emergence of "regulatory competition" in the Netherlands, which provides constant pressure in the adjustment of Dutch waste policies. The particular mechanism of regulatory arbitrage-industry pressure for a level playing field-is familiar from the international arena, but the following section is a reminder that regulatory arbitrage can be equally significant on the subnational regulatory level, i.e. in this case, among the Dutch provinces.

A direct consequence of integration in the waste market was that it increased the visibility of idiosyncratic differences of the provincial rules. Waste companies, operating for the first time on a national scale, were confronted with provincial differences in licensing requirements that implied significantly varying investment constraints. For example, regulation in the province of Gelderland obliged a new incineration facility to be equipped with capacity for energy recovery for it to be issued an operating license. In other provinces, however, capacity for energy recovery would be an option, but not a requirement for obtaining a license. The costs of this particular investment typically range over millions of guilders, and thus competitive distortions to that

28 For a comprehensive catalog of typical integrator services, see the range of waste management services listed in note 27. 
amount were created in the market by this type of provincial rule variation. ${ }^{29}$ Grown to the size of the national market, the integrators were sufficiently powerful as an industry to lobby the ministry to abolish these differences, which resulted in a centralization of policy-making at the ministerial level.

Another case demonstrates that not only different regulations, but also the differential enforcement of otherwise similar regulatory requirements may cause competitive distortions that collectively are serious enough to alter companies' lobbying incentives. An illustration of this was the provincial licensing requirement to install support-burners in an incineration facility. In order not to allow the temperature within the oven to drop below a certain level, the use of support burners was mandated in every province. However, daily practice has demonstrated that these burners are not strictly necessary since the caloric value of present-day waste is sufficiently high to reach minimum oven temperatures under virtually all conditions. Some provinces acknowledge this practice and tolerate a departure from this requirement. Others, however, stuck to the letter of the law and continued to mandate support-burners. This particular requirement was alleged to produce an investment distortion of several hundred thousand guilders. ${ }^{30}$

Not surprisingly, the integrators have called upon the Dutch central administration (VROM) to abolish provincial boundaries and to rationalize and centralize at least the waste policy rules on the book, so as to provide consistency in the sector and a level playing field. These changes have been adopted. Provinces have been stripped from general planning and coordination responsibilities, whilst provincial boundaries for waste streams have been dropped since Jan, 1 2000. The policy change - concentrating the formulation of licensing and operating conditions for waste management services with the Ministry ${ }^{31}$ — created a national market and a level playing field for waste management companies at least as regards the competitive conditions of landfill and incineration facilities. $^{32}$

What continues to be problematic, however, is the differential enforcement of waste management rules and licensing conditions, i.e. the concrete monitoring and enforcement practices which are, and continue to be, carried out by a host of decentralized actors - the provinces, mu-

29 See René Didde, Handhaving afvalbedrijven vereist nieuwe aanpak, (Verification of regulatory compliance by waste companies requires a new approach) available at Dutch Waste Processing Association's (VVAV) Afvalforum (Waste forum) website: http://www.vvav.nl/nw_AF_1200_compl.html

30 according to Wim Koole, one of the directors at AVR, who is cited in René Didde, Handhaving afvalbedrijven vereist nieuwe aanpak, see n.28

31 It is not a complete formal centralization. Formally, licenses are still handed out by the provinces for waste management facilities. However, the conditions which these licenses have to fulfil are dictated by the Ministry and individual licensing and siting decisions have to be approved by the Minister by a so-called "Verklaring van Geen Bezwaar" (declaration of no objection).

32 For now, liberalization stops at the Dutch borders. This is because the Dutch administration fears unfair competition from foreign waste haulers who would creamskim the market by competing on lower final disposal costs. However, given the rapid technological developments in the waste market-especially the promising development of biomass applications for fuel and as a raw material (substitute for oil)—it seems that the process of integration in the waste sector will not stop with the size of the national market or the "natural" boundaries of the sector. Indeed, this is already witnessed by the activities of French, Belgian and British firms operating in the Netherlands as well as it is by the successful entry of an energy producer, Essent into the Dutch waste market. 
nicipalities and waterboards - in the context of the actual day-to-day provision or updating of an operating license. There are still considerable differences in the licensing practices among these different authorities, which is sometimes sufficient cause for industry complaint, especially given the good faith efforts of many companies in the area of environmental management. In the next section, we will examine this issue and the way administrative authorities have responded in more detail.

\section{The Impact of Environmental Management Systems on Govern- ment Licensing}

In the following I will discuss changes at the micro or local level, i.e. within companies and within the licensing practices of the provinces, municipalities and waterboards responsible for granting the operating license and for day-to-day inspection. These changes are intimately related to the relatively recent company adoption and spread of so-called organizational standards. The relevant ones for our purposes are the ISO 14001 and the European EMAS standards, which describe the disciplines necessary to implement environmental management systems within companies. $^{33}$

The increasing variation in environmental performance at the company level following the adoption of environmental management systems has nourished a growing demand among provinces, municipalities and waterboards for more flexibility in the application of licensing requirements. In 1995, the Ministry started to experiment with an approach to streamline licensing aimed at individual company requirements, but without losing general consistency and legal certainty in the overall enforcement of licensing. ${ }^{34}$ This policy of flexible licensing came to be known as "Vergunning op Hoofdzaken" (VOH) and "Vergunning op Maat" (VOM)-i.e. licensing on major criteria and tailor-made licensing, respectively. The flexible licensing policy is based on the

33 For a discussion of the ISO 14000 environmental management standards from a strategic management perspective, see generally Don Sayre, Inside ISO 14000, The Competitive Advantage of Environmental Management, CRC Press, St. Lucie Press, 1996. On ISO 14000 more critically, see Pierre Hauselmann, ISO inside out - ISO and environmental management. Surrey, WWF International Discussion Paper, Second Edition, 1997. For an early academic "law and society" view of the implications of private environmental certification programs for law and the legal process, see Errol E. Meidinger, Private Environmental Certification Programs and US Environmental Law: Closer Than You May Think, Environmental Law Reporter, vol.31 no.2, 2001 p.10162 - ff. Meidinger emphasizes the functional homology between private certification programs and standard legislative and regulatory procedures which demonstrates the small gap existing between them, and which allow ISO standards, in his view, to be incorporated easily by the legal system. This view, however, disregards and discounts the practical dimensions of the problems related to private compliance and the public verification of such compliance for reasons of due process and policy coordination. The problems relate to the reconciliation of corporate efficiency demands with public policy and accountability demands. This reconciliation requires different institutional forms-e.g. ISO 14000 standards and juridical compliance factsheets - to interconnect with one another in a not yet institutionally determinate way. Hence, practitioners tend to view formal incorporation by the legal system more skeptically. As will be mentioned below, practitioners and regulators alike fear juridification of ISO 14000 standards which would stifle and hinder the effectiveness of day-to-day implementation of environmental management systems.

34 The relevant document is, the 'handreiking' "Bedrijfsinterne milieuzorg als basis voor een andere relatie tussen overheden en bedrijven", (Corporate environmental care as the foundation for a new relationship among public authorities and corporations) published in October 1995 by VROM. 
general licensing authority provided to the executive by the relevant provisions of the parliamentary "Wet Milieubeheer" (law on environmental management). It is perhaps interesting to note that no explicit legal changes were required in the law to accommodate the new policy. ${ }^{35}$ The policy was distributed in a so-called circulaire, a document that does not reach the level of a ministerial regulation, but can be seen more or less as an informal memo from the minister to relevant parties in the bureaucracy and in civil society. ${ }^{36}$ It was made, however, in participation with and with the broad support of all relevant implementation actors. ${ }^{37}$ The circulaire consists of two parts that combine the dual purpose of the $\mathrm{VOH}$ policy, i.e. to provide regulatory flexibility to corporate licensees while at the same time securing legal certainty and enforceability in the interest of a uniform national licensing policy. ${ }^{38}$ Part one describes the global characteristics of the policy and the policy instruments "VOH" and "VOM". It aims to supply a general framework of reference within which parties can conduct licensing negotiations with a view towards maintaining regulatory flexibility. ${ }^{39}$ Part two is a series of legal fact sheets which describe relevant legal aspects that need to be covered when issueing a VOH or VOM. Significantly, it also contains concrete organizational design recommendations for local governments to facilitate the implementation of flexible licensing. ${ }^{40}$

Let us examine the operating conditions for licensing on the basis of major criteria (VOH). The use of the $\mathrm{VOH}$ license is predominantly anticipated for large companies. It aims to maximize corporate flexibility in the pursuit of environmental objectives. The use of the VOM, by contrast, is meant for small and medium enterprises and offers less flexibility in licensing practices than the VOH. For large companies, the requirements to apply for a VOH are as follows.

Companies must:

1) Possess a government approved environmental business plan;

2) Conduct an ISO 14001 or EMAS certified environmental management system;

3) Publish an annual environmental report;

“Wegwijzer Vergunning op Hoofdzaken, Vergunningverlening op Maat”, p.10

The circulaire is called "Wegwijzer Vergunning op Hoofdzaken, Vergunningverlening op Maat" (Licensing on Major Criteria, Tailor-Made Licensing), [henceforth, "Vergunning op Hoofdzaken"] publicatie Ministerie van Volkshuisvesting, Ruimtelijke Ordening and Milieubeheer (VROM), August 1999. This publication extends the former VROM document, "Bedrijfsinterne milieuzorg als basis voor een andere relatie tussen overheden en bedrijven”, (Corporate environmental care as the foundation for a new relationship among public authorities and corporations) October 1995.

These actors were the Directoraat-Generaal Rijkswaterstaat (an important Dutch inspection authority) of the Ministry of Verkeer en Waterstaat, the Interprovinciaal Overleg IPO (interprovincial platform), de Unie van Waterschappen UvW (Union of Waterboards), and the Vereniging van Nederlandse Gemeenten VNG (Association of Dutch Municipalities).

This was a strong demand of the office of the public prosecutor at the Department of Justice.

Flexibility is defined in three ways: (1) as to the choice of means with which to accomplish environmental objectives, i.e. material flexibility; (2) a quick implementation of production and process changes without elaborate procedural requirements in the license, i.e. procedural flexiblity; and (3) the selection of priorities among environmental objectives, which is denoted as temporal flexibility

“Vergunning op Hoofdzaken”, supra n.35 p.116-ff. 
4) Maintain maximum disclosure and transparency to third parties about their environmental performance;

5) Show encouraging compliance behavior with regard to existing licensing requirements.

The Dutch approach to flexible licensing relies on a conceptually strong combination: an environmental business plan and an externally certified ISO 14001 system. The environmental business plan is a plan that contains the environmental goals of the company and the time frame and trajectory in which the company anticipates to achieve these goals. The environmental business plan grew out of the so-called "target-group" approach the Dutch government developed in the mid-eighties in which the ministry decided to develop sector-specific environmental targets for which achievement sector-specific environmental business plans were developed. ${ }^{41}$ Negotiations between the ministry and industry sector associations resulted in industry-specific sectoral covenants which detailed the contribution each industry was supposed to deliver to attain the global objectives as laid down in the National Environmental Plan ("Nationaal Milieuplan"). Sectoral environmental business plans thus act as the coordinative interface between local—i.e. company level-environmental efforts and their translation into national environmental performance objectives. At the company level, the environmental business plan is primarily a planning and tasksetting document without containing specific implementation measures at the workshop level.

This is where the coupling with environmental management systems is intended to produce positive synergy effects. Where the environmental business plan serves to specify company tasks and targets vis-à-vis the government, ISO 14001 systems promise to provide the means with which individual companies hope to achieve those targets. The distinctive feature of ISO 14001 standards is that they do not specify which environmental targets to achieve, but are restricted to specifying the management disciplines and practices which a company may engage in in order to better its environmental performance. This is what makes them organizational standards, and not environmental standards. ${ }^{42}$

ISO 14001 environmental management systems are not only internal management standards, but can provide assurance to third parties-i.e. the local community, but also in principle national policy-makers-by relying on external certification. ${ }^{43}$ The Dutch government has set up a foundation for coordinating the certification of environmental management systems (henceforth SCCM, for "Stichting Coordinatie Certificatie Milieuzorgsystemen"), which regulates the quality and the uniformity of certification services. In essence, SCCM regulates three matters: (1) the interpretation of the ISO 14001 norm; (2) requirements about the internal organization of the

41 General sectoral environmental business plans were only developed for industry sectors with sufficiently common production processes (e.g. the graphics industry). Industry sectors with divergent production processes were encouraged to develop company-specific environmental business plans. See generally, P-J. Klok and S.M.M. Kuks, Het Doelgroepenbeleid in: Milieubeleid-een beleidswetenschappelijke inleiding, supra n.5, p.79-ff.

42 See generally, Don Sayre, Inside ISO 14000, The Competitive Advantage of Environmental Management, supra n. 32

43 See Erroll E. Meidinger, Private Environmental Certification Programs and U.S. Environmental Law, supra n.32 p. 10163 
certifier; and (3) requirements about the operation of the certifier. Certifiers have to contract with SCCM in which they pledge to adopt - with minor deviations - the certifiation system developed by SCCM. In addition, certifiers must be accredited with the Council of Accreditation ("Raad voor Accreditatie").

It is apparent that the $\mathrm{VOH}$ approach relies largely upon the available internal capacity of the company to fully integrate environmental improvement into their production processes, and to measure, document and report in a credible way to third parties the results of such environmental improvement efforts. Emphasis is placed on the company's internal responsibility and on the flexibility with which it can pursue its own environmental objectives within the framework of the general licensing criteria. ${ }^{44}$ Consequently, a license on major criteria contains-preferred quantified-contextualized goal prescriptions rather than so-called means prescriptions that fix the techniques with which environmental objectives are to be reached. In this respect, it is a significant departure from "command and control" regulation, which would lay down the obligations to which the responsible party would be held as exactly and administratively conveniently as possible. In effect, this would frequently entail fixing the technology ("best available technology" BAT principle) or specifying a range of methods by which a certain limit value would need to be reached (as in emissions regulation where the choice of instruments would be free as long as a limit value of emissions clean-up was reached).

It is clear that the success of such a policy depends critically on the quality of the information shared and the quality of cooperation between the company and the licensing authorities. As indicated, external accreditation of ISO certified companies and the environmental business plan provide the basic platform on the basis of which licensing negotiations are being conducted. However, in practice these systems are stepping stones towards, rather than pillars of, the decision to grant a license. In other words, the presence of these systems is indicative of, but not evidentiary of compliance with licensing requirements. In this regard, a complete coupling of formal legal requirements with the provisions in environmental management systems or the environmental business plan is not envisaged; neither is it considered to be desirable. ${ }^{45}$ This is because both firms and licensing authorities alike worry about a possible juridification of the provisions in environmental management systems, which would hamper operational efficacy. ${ }^{46} \mathrm{Con}$ sequently, there are more important things than just having an EMS in place. These relate to the company's capacity to credibly demonstrate the following material requirements in the licensing negotiations with the government:

(1) The quantified environmental effects of the company's activities;

(2) The degree to which, and the manner in which, these environmental effects can be limited;

44 In this respect, the policy of flexible licensing shows a general fit with the "target-group policy" of the Dutch government which tries to address specific constituencies with specifically directed measures in an explicit effort to stimulate social learning ("verinnerlijking", i.e. moral internalization, is the Dutch word used in this regard).

45 See "Vergunning op Hoofdzaken", supra n.35 p.21

46 Idem 
(3) Concrete information about the implementation of the environmental management system and how it relates to compliance with licensing requirements. ${ }^{47}$

Likewise, the continuing enforcement of such a policy relies heavily on the quality of the information shared and the quality of cooperation among the company and its government counter part. In this regard, it may be interesting to note that there are indications that an ongoing dialogue is taking place amongst vested companies and their relevant licensing partners. This is not the place to elaborate on the practical details of this dialogue. However, the interesting feature of this dialogue, for our purposes, is that it is increasingly being standardized by the formation of a common language of compliance. One example may perhaps be sufficient to illustrate this incipient development and to hint at its potential ramifications.

AVR, one of the previously mentioned integrators, recently started to experiment with a socalled compliance program in two of its subsidiary firms. This is an internal control system promoted in the Netherlands by a legal consultancy bureau called "Legal Accountability". ${ }^{48}$ Basically, the compliance program furnishes customized information to management, directors, and the supervisory board about the company's compliance with legal requirements. It is perhaps best seen as an ongoing database which demonstrates the current environmental state of affairs of facilities, where modifications in the license are required; and it also acts as an early warning system if certain legal limit values are reached and legal action or reporting obligations are required. $^{49}$

The explicit development of a common language should help considerably in the mutual effort to communicate clearly the complicated nature of environmental performance commitments, and it should help create a climate of mutual trust among companies and authorities. Such general trust is necessary to foster confidence that each participant is competent to formulate and abide by mutually agreed upon environmental commitments. It must be stressed, however, that ministerial efforts to achieve coordination and integration of environmental waste performance on the basis of information obtained from flexible licensing practices have hardly begun. This is largely because the need for such coordination has, until recently, not been perceived. ${ }^{50}$

47 See "Vergunning op Hoofdzaken", supra n.35

48 The consultancy bureau is headed, interestingly enough, by a former public prosecutor of environmental law, Henriette Gelinck. The compliance program is described in René Didde, Handhaving afvalbedrijven vereist nieuwe aanpak, (Verification of compliance by waste companies requires a new approach) available at Dutch Waste Processing Association's (VVAV) Afvalforum (Waste forum) website: http://www.vvav.nl/ nw_AF_1200_compl.html

49 Idem

50 Apart from increased cooperation between companies and authorities, the LMC initiative has also led to increased cooperation among licensing authorities themselves. In many cases, licensing among provinces, municipalities and waterboards is coordinated so as to provide a one stop shop solution to companies that apply for a LMC. However, to this author's knowledge, no effort has as yet been made to harvest and aggregate the information obtained from the flexible licensing process so as to formulate and update national environmental policies and targets. 


\section{The Impact of Market Expansion and Cooperative Licensing on Corporatist Governance}

This brings us to my original concern with the continuing evolution of modes of governance and legal regulation. I have earlier defined environmental corporatism as a mode of governance dependent on associational politics, which is structured by the need of associations to heed the logics of membership and influence. In order to be able to show the shift from associational politics to new modes of regulatory policy coordination, I have to demonstrate how the combined forces of market and techological change jointly affect the characteristic mode of corporatist governance as typified by the packaging covenant. Hence the questions that I am posing in this section are the following: How are market expansion and the ISO 14001 environmental management systems likely to affect environmental corporatism in general? And what specific impact are they likely to have on packaging waste policy as now embodied by the packaging covenant and the aforementioned corporatist structure set up and administered by SVM-Pact?

To recapitulate what has been said about the corporatist mode of governance, policies that need to be provided across industries - such as packaging waste reduction policy or environmental policies more generally - are traditionally thought to demand cross-sectoral interest aggregation for policy formulation (the logic of membership). This requirement in turn is thought to push industry to set up issue-specific associations and to engage in associational politics to influence government policies (the logic of influence). ${ }^{51}$ The packaging waste case study suggests that these political incentives for aggregation and association may become subject-in the medium to long run-to a strategic shift, at least as regards the state mandated provision of cross-sectoral common goods such as environmental protection. This is because the combined impact of market expansion and cooperative licensing is to produce more choices-in addition to the choice of associational politics - for both companies and governments regarding the adaptation to the requirements of common goods provision. The next section presents these choices in their concrete detail.

In the messy combination of the 'old' and 'new' world that holds sufficient room for the packaging covenant, professional waste integrators and ISO 14001 systems to co-exist snuggly together, companies basically have three options to fulfil government obligations to reduce packaging waste. The first option is the existing option provided by the packaging covenant: companies-to the extent that they are willing - can sign up with the packaging covenant and fulfil the substantive packaging reduction and administrative reporting obligations to which they have voluntarily committed themselves.

In the case of a company operating on a $\mathrm{VOH}$ license, the second option is to negotiate specific waste reduction targets directly with the relevant licensing authority through the flexible licensing process afforded by the $\mathrm{VOH}$ approach. In fact, cooperative licensing might lead companies to prefer direct negotiation with relevant government authorities about waste management op- 
tions to external representation through associative action. This is because environmental management licensing requirements can be tailored to match company production processes more precisely and can be updated on a periodic basis in a way that does not harm the efficiency of corporate production. In turn, the most important regulatory benefit for government associated with cooperative licensing is that companies are provided with a concrete incentive to continuously improve their environmental performance. This is because regulators-as was discussed before-can reward companies with a recognized environmental track record with individual and "preferential" licensing treatment. Moreover, regulators are afforded an additional avenue for strengthening their governance authority. This is by conducting an explicit innovation policy, e.g. the pooling of individual corporate experience allows single innovations to spread and it permits the regulator to adopt some sort of helpdesk function vis-à-vis ailing companies. ${ }^{52}$

The third and institutionally most complex option for delivering environmental waste management is provided by the market and is afforded by the presence of specialist firms with integrated waste management services (the integrators). This affords companies the choice of outsourcing waste management requirements to waste specialists who can in principle also make sure that the company complies with relevant environmental regulations, including the packaging covenant. It is important to stress, however, that the market does not present these options autonomously and without state intervention in the areas of public and private law. To a significant degree, the very market for these integrators is sustained by credible state commitments to waste reduction and recycling that in fact dictate what constitutes adequate waste management (environmental goals, 'public' law). As we have seen, the state is also needed to level the playing field so as to equalize the conditions for market provision ('market-setting', 'private' law). A further, and less obvious, need for state action, however, relates to the need for the state to coordinate local regulatory efforts so as to retain the capacity to conduct national policies. This goal requires coordinative institutions (currently lacking in the Dutch institutional context) that can tighten the link between local inspection and enforcement and the setting and updating of national policy. Concretely, this means that certain information systems (akin to the sector environmental business plans that coordinate at the sectoral level) will need to be implemented in order to streamline and integrate local company-performance data collected by local licensing authorities into the political process that defines national environmental goals and policies (organizational regulation, 'public' law). In addition, it is clear that sufficient institutional guarantees will have to be designed to ensure that information that the integrators present on the performance of another company is credible (information regulation, 'private' law). Nonetheless, given that the waste market-as supported

52 See generally, the work of Charles Sabel, who lays out an experimentalist institutional design for democracy that combines local, decentralized problem-solving with a capacity for central coordination and dissemination of experimentalist results. See Michael C. Dorf and Charles Sabel, A Constitution of Democratic Experimentalism, in 98(2) Columbia Law Review (1998) p.267-473; Charles Sabel, Archon Fung, and Bradley Karkkainen Beyond Backyard Environmentalism (Joshua Cohen, ed. 2000), Sabel, Charles, Dara O'Rourke and Archon Fung (2000), Ratcheting Labor Standards: Regulation for Continuous Improvement in the Global Workplace, Washington, D.C.: The World Bank, Social Protection Discussion Paper No.11.; Also, Charles Sabel and James Liebman, The Emerging Model of Public School Governance and Legal Reform: Beyond Redistribution and Privatization," paper presented at the Montreal Conference of Collective Rights, Identity and Public Education, June 2000 (on file with author) 
by the current regulations-structures the integrators' incentives to supply this service as adequately as they can, especially the latter design problem should not be particularly severe.

However, this is not the place to work out the details of the particular regulatory infrastructure that could support the new political economy of waste management. Let me therefore stop here by simply outlining the nature of the institutional design problem while leaving a-more satisfactory-fuller treatment of the regulatory strategy of organizing legal markets for common goods for another occasion. ${ }^{53}$ What I want to do, instead, is to return momentarily to the current case study to investigate how the incentives - and with that, possible future transition pathsmay look that can lead to a full-fledged market for environmental waste management services in the Netherlands.

One scenario might speculate on the flexibility with which corporatist structures are able to adapt to their environment. For example, the current SVM-Pact experience shows that, for those ISO certified companies who already work with environmental management systems, the covenant reporting obligations are fulfilled simply by culling the data from existing environmental reports generated by the ISO practices. As a result, SVM-Pact is investigating how to streamline its cluster questionnaire and its monitoring practices with the formats generated by ISO standards. ${ }^{54}$ It is thus apparent that the existing corporatist structure may absorb the new technology and use it to improve its own coordinative capacity and to continue to guarantee government of its capacity to deliver corporate commitments.

On the other hand, however, one must take into account that from the perspective of a company with a VOH or VOM license, signing up to the packaging covenant becomes increasingly less attractive. This is because it is reasonable to think that where companies already have to justify their general environmental performance vis-à-vis local licensing authorities, companies might come to view the extra waste reporting requirements of the covenant as simply more administrative paperwork that would not deliver any additional environmental benefit. ${ }^{55}$ In turn, for reasons of reliability and control, governments might prefer access to individual company data to aggregate figures collected by sectoral associations, even if it means that governments now must incur the costs for collecting, aggregating and interpreting corporate environmental data on their own, instead of outsourcing those costs to business associations.

What seems certain is that the combination of environmental markets and cooperative licensing in general is likely to lower the incentives for companies, as well as for government, to engage in cross-sectoral interest aggregation and associational politics in order to formulate industry-wide

53 See generally, Henri Tjiong, The Political Economy of Regulatory Competition, A Diachronic Theory of Institutional Change in an Era of Globalization, chapter five, author's dissertation (forthcoming)

54 This information was obtained in an interview with Mr. Rob van Beek, officer at SVM-Pact.

55 Indeed, there seems already to be evidence for a failing participation rate associated with the covenant which is reported in the latest annual report of the Packaging Committee. Recall that the goal of the covenant was to reach a $90 \%$ packaging coverage ratio, that is to have $90 \%$ of the packaging marketed be included in the covenant. This target has not been reached. In 1998, the packaging coverage ratio was 66\%. In 1999 however, the coverage ratio further dropped to 59\% despite adamant and increased efforts of SVM-Pact to enlist more companies into the covenant. 
environmental commitments that can be aggregated into national plans. At the level of the nation-state, this is a surprising result, as the demise of corporatism is mostly associated with the practical obstacles to organizing positive coordination at the international level. ${ }^{56}$ By contrast, this study shows that positive coordination at the national level may not be adequate enough to sustain environmental corporatism in the face of supplemental market and organizational strategies of companies. From a general perspective, it is increasingly becoming clear that market and technological change is eroding the capacity of associations to offer incentives to their members to engage in associational politics in the interest of the collective good. However, as corporatist structures are well-known for their resistance to structural transformation, it may be premature to speculate on a possible internal collapse of domestic corporatism in the area of waste policies. ${ }^{57}$ For the future it remains to be seen whether altogether new regulatory structures will be implemented in order to exploit the coordinative potential of new regulatory technologies or whether the new coordinative potential associated with ISO 14001 systems will be absorbed by the existing corporatist structure of associations. The selection among these two possibilities will largely depend on whether individual companies choose to hold on to existing channels of government communication or to utilize the new possibilities afforded by flexible licensing to build new relationships with relevant authorities.

In conclusion, what is apparent is that despite corporatism's often quoted robustness and persistence, ${ }^{58}$ the frequently mentioned role that associations play as private interest governments ${ }^{59}$ is no longer an uncontested one. In the face of increasing social demands and organizational complexity, other possibilities and models of regulatory coordination develop that combine more flexibility for individual companies with more reliability and control for government. Regard-

56 Wolfgang Streeck and Philippe Schmitter, From National Corporatism to Transnational Pluralism: Organized Interests in the Single European Market, in 19 Politics \& Society, no. 2 (1991), p.133-164

57 See generally, Philippe C. Schmitter, Corporatism is dead! Long live corporatism! in Government and Opposition, 24 (1989) p.54-73.

58 Cf. Peter Katzenstein who describes the ability of corporatist structures to resist structural transformation in the following terms: "The political staying power of corporatist structures is reflected in the way that these structures constrain the building of political coalitions that might fundamentally challenge existing institutions and policies. Such coalitions are made possible by recurrent cycles of industrial innovation, maturation, and imitation that redefine the economic and political interests which different actors have in the international economy. Major firms and industry associations react to new circumstances by fashioning new coalitions to press for political changes that may be as specific as particular industrial adjustment policies or as general as broad regime characteristics. Because corporatist structures encourage flexibility, collaboration, and the absorption of the political consequences of economic dislocations, alternative political coalitions are not easily formed. The political logic inherent in the corporatist structures of the small European states instead enhances political predictability and incremental adjustment. These structures narrow power differences and link state and society intimately. They thus succeed in capturing potential coalitions among changing political forces and in channeling political energies into the relegitimizing of corporatist arrangements." Peter Katzenstein, Small States in World Markets, supra n.1 p.198. However, in contrast to Katzenstein's otherwise internally logical argument, institutional change need not arise from explicit political coalitions, but can be the result of external forces which imply a subtle shift in the government and corporate incentives sustaining corporatism. More concretely, corporate and government incentives respond to outside market and technological forces which create social expectations for coordination that tax the structure of corporatist governance beyond its capacity in ways here described.

59 See generally, W. Streeck \& Ph. Schmitter (eds.), Private Interest Government, London: Sage, (1986) 
less, however, of how the choice may fall, it is to be expected that corporatist structures will transform, or risk becoming obsolete in a way that was not anticipated before. ${ }^{60}$

60 Already in 1979, Philippe Schmitter speculated on the possibilities of an institutional transformation and/or a possible demise of associational corporatism. He identified four possible main scenarios. Scenario \#1 consisted of rank and file revolts out of frustration of political aspirations or identity: Especially from corporatism's protagonists (i.e. the major corporations) whose likelihood is mitigated by the use of incumbent resources (licenses, permits binding arbitration). Scenario \#2 envisioned class mobilization: According to marxists, corporatism is a strategy for buying time, but cannot change the structural contradictions of capitalism and when workers become conscious of the 'rigged game' they will rebel against it. Scenario \#3 relied on change from entitled organizations: Corporatism would implode if interests upon which the costs of corporatism used to be devolved, were to organize themselves into hierarchically structured, offically sanctioned associations. Previous externalities would become internalized within the expanding system of organized interest politics and would make decisions vastly more difficult. Scenario \#4 envisioned the impact of singleissue movements: New interests cannot be contained within the bounds of interest intermediation, and spill over into other forms of collective political activity: public interest lobbies, grass-roots movements and green parties. Note that the current scenario for corporatism's transformation due to market and technological change, although not squarely among these four, does resonate with Schmitter's first scenario in so far as institutional change is not to be expected from political revolution by outside players, but from a quiet incentive shift on the part of its internal players and apparent beneficiaries. This paper can be summarized as describing precisely how market and technological change can be conceptualized as the forces underpinning this hypothetical incentive shift. See generally Philippe Schmitter, Reflections on Where the Theory of NeoCorporatism Has Gone and Where the Praxis of Neo-Corporatism May Be Going, in: Patterns of Corporatist Policy-Making, supra n.6 p.274 